\title{
Fungal colonization of the brain: anatomopathological aspects of neurological cryptococcosis
}

\author{
ANA CAROLINE COLOMBO ${ }^{1,2}$ and MARCIO L. RODRIGUES ${ }^{1,3}$ \\ ${ }^{1}$ Instituto de Microbiologia Paulo de Góes, Universidade Federal do Rio de Janeiro, \\ Avenida Carlos Chagas Filho, 373, CCS, Bloco I, sala 030, 21941-902 Rio de Janeiro, RJ, Brasil \\ ${ }^{2}$ Programa de Pós-Graduação em Química Biológica do Instituto de Bioquímica Médica Leopoldo de Meis, \\ Universidade Federal do Rio de Janeiro, Avenida Carlos Chagas Filho, 373, CCS, \\ sub-solo do Bloco D, 21941-902 Rio de Janeiro, RJ, Brasil \\ ${ }^{3}$ Centro de Desenvolvimento Tecnológico em Saúde da Fundação Oswaldo Cruz (CDTS-Fiocruz), \\ Avenida Brasil, 4036, Sala 814, Manguinhos, 21041-361 Rio de Janeiro, RJ, Brasil
}

Manuscript received on December 19, 2014; accepted for publication on February 9, 2015

\begin{abstract}
Brain infection by the fungus Cryptococcus neoformans results in an estimated 500,000 human deaths per annum. Colonization of the central nervous system (CNS) by C. neoformans causes different clinical syndromes that involve interaction of a number of fungal components with distinct brain cells. In this manuscript, our literature review confirmed the notion that the Cryptococcus field is expanding rapidly, but also suggested that studies on neuropathogenesis still represent a small fraction of basic research activity in the field. We therefore discussed anatomical and physiological aspects of the brain during infection by $C$. neoformans, in addition to mechanisms by which brain resident cells interact with the fungus. This review suggests that multiple efforts are necessary to improve the knowledge on how C. neoformans affects brain cells, in order to enable the generation of new therapeutic tools in a near future.
\end{abstract}

Key words: Fungal Infections, Cryptococcus, meningitis, meningoencephalitis.

\section{INTRODUCTION}

Fungal infections are now considered a neglected epidemic in HIV patients (Armstrong-James et al. 2014). It is estimated that more than one million people die each year because of systemic fungal infections (Armstrong-James et al. 2014). These numbers are comparable to those determined for malaria and tuberculosis (Park et al. 2009).

Fungal infections of the central nervous system (CNS) are highly lethal. The most common fungal

Correspondence to: Marcio L. Rodrigues

E-mail: marciolr@cdts.fiocruz.br pathogen infecting the brain is Cryptococcus neoformans, an encapsulated yeast-like pathogen that is highly efficient in causing damage to immunosuppressed human hosts (Price and Perfect 2011). The considerable medical importance of $C$. neoformans led to a huge increase in the interest of the biomedical scientific community on this model. In the past three decades, the number of scientific publications in the field has increased exponentially (Fig. 1). A similar profile has been observed in publications including Brazilian authors (Albuquerque and Rodrigues 2012), which probably reflects the fact that human cryptococcosis 


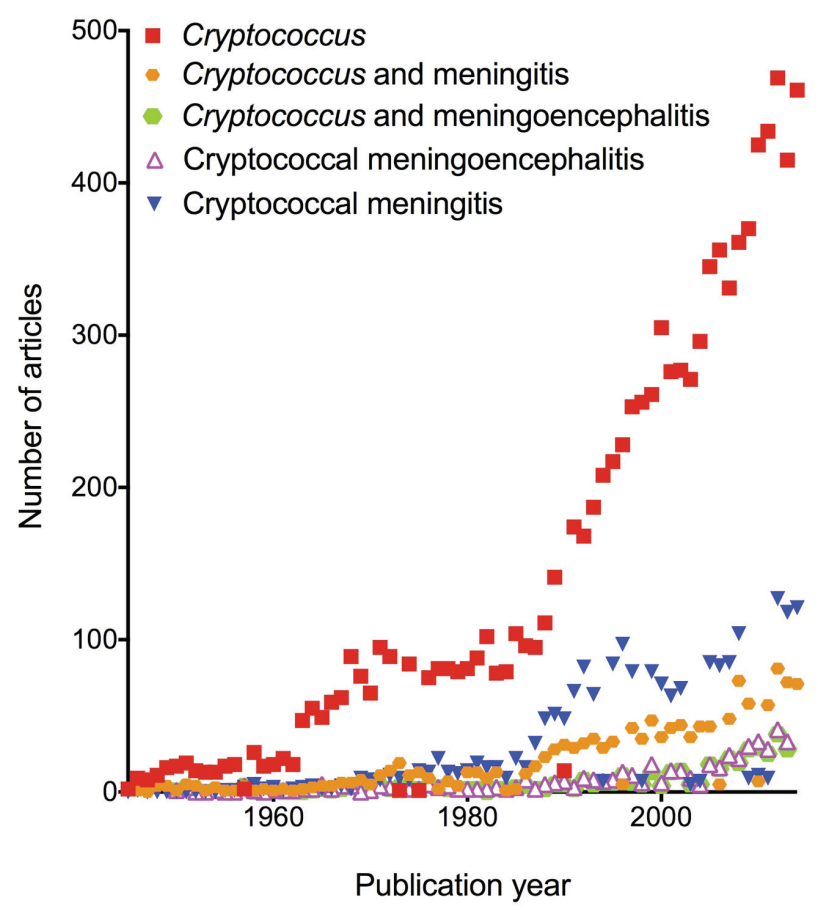

Fig. 1 - Pubmed-indexed papers on Cryptococcus and / or related brain diseases published between 1945 and 2014. The annual number of papers was obtained after a Pubmed (http:// www.ncbi.nlm.nih.gov/pubmed/) search using the keywords listed on the top of the Figure. Increasing trends were observed in all cases. Article quantification on Cryptococcus-related brain diseases (meningitis and meningoencephalitis) is likely overestimated, considering that the terms commonly used for pathology description are widely used to introduce regular articles and reviews in the Cryptococcus field.

is the most fatal fungal infection in AIDS patients in Brazil (Prado et al. 2009). In recent years, the medical importance of the sibling species C. gattii has also become evident (Lester et al. 2011). C. gattii causes lethal pulmonary infections in immunocompetent patients (Brizendine et al. 2011). Both C. neoformans and C. gattii produce extracellular, capsular polysaccharides that are highly deleterious to the host immune system (Zaragoza et al. 2009).

Although C. neoformans infection is directly associated with human mortality resulting from neurological disorders, knowledge on how the

\section{$\square$ Brain disease/pathogenesis General topics}

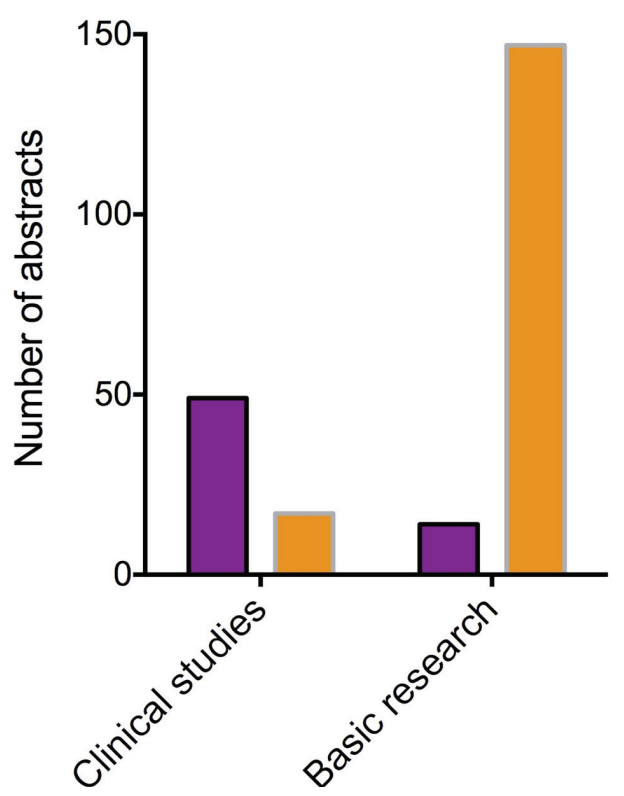

Fig. 2 - General distribution of research activity in the area of Cryptococcus and cryptococcosis. Abstracts presented in the most recent international conference on Cryptococcus and cryptococcosis (May 2014, Amsterdam) were individually analyzed and classified into general topics or brain disease and/or pathogenesis. This analysis revealed that studies on brain disease predominated in the clinical area, which probably reflects the fact that meningitis and meningoencephalitis are the most serious clinical conditions in human cryptococcosis. In basic research, however, studies on brain disease and/or pathogenesis composed a minor fraction of scientific activity.

fungus causes damage to the brain is still limited, which likely correlates with the inefficacy of the currently available regimens for treating brain cryptococcosis (Roy and Chiller 2011). Basic research activity on Cryptococcus and cryptococcosis is not generally focused on brain pathogenesis, as concluded from quantification of the number of abstracts focusing on neurological cryptococcosis presented in the last $\left(9^{\text {th }}\right)$ edition of the International Conference on Cryptococcus and Cryptococcosis (May 2014, Amsterdam) (Fig. 2 ). It is clear, therefore, that collective efforts are necessary to connect basic knowledge on how $C$. 
neoformans affects brain cells with the possibility of generation of new therapeutic tools. In this article, we discuss basic aspects of the pathogenesis of neurological cryptococcosis, aiming at raising new questions to be potentially addressed in future studies on the $C$. neoformans pathogenic model.

\section{MELANIN AND NEUROTROPISM}

C. neoformans primarily reaches the lung after inhalation of environmental cells and disseminates to the brain in the immunosuppressed host. After penetrating host tissues, C. neoformans can produce either latent infection or acute disease (Chayakulkeeree and Perfect 2006). Inoculum size, virulence of the infectious strain and the host immune status are unquestionably important for disease progress. Therefore, the severity of cryptococcosis depends on the balance between the host immune response and the pathogenic arsenal produced by $C$. neoformans (Chayakulkeeree and Perfect 2006, Terada 2010).

The fungus produces melanin during mammalian infection (Nosanchuk et al. 1999, Nosanchuk et al. 2000, Rosas et al. 2000). Melanin synthesis requires laccase, an enzyme that catalyzes pigment polymerization in the presence of phenolic compounds, such as L-DOPA (Nosanchuk et al. 2000, Zhu and Williamson 2004). Intracellularly synthesized melanin is transferred to the cell wall (Eisenman et al. 2009), turning melanized $C$. neoformans cells less susceptible to antifungals, phagocytosis, reactive oxygen and nitrogen species, antimicrobial peptides and ultraviolet radiation (Nosanchuk et al. 2000, Rosas et al. 2000). Laccase was one of the first virulence factors characterized in C. neoformans (Salas et al. 1996). In fact, studies with human patients demonstrated that high laccase activity correlated with increased survival of $C$. neoformans inside macrophages and in the cerebrospinal fluid (CSF) (Sabiiti et al. 2014). The enzyme has been suggested to convert catecholamines into potentially toxic quinines (Liu et al. 1999).
The predilection of C. neoformans for the brain has been correlated with the presence of high concentrations of precursors for laccase activity (Nosanchuk et al. 2000, Zhu and Williamson 2004). In fact, the human brain contains abundant concentrations of phenolic compounds, including norepinephrine, 3,4-dihydroxyphenylacetic acid, homovanillic acid, 5-hydroxyindolacetic acid, serotonin, and dopamine (Nosanchuk et al. 2000, Sabiiti et al. 2014). The latter is a neurotransmitter involved with the regulation of motor activity, cognitive processes, modulation of motivational functions (reward) and defensive mechanisms (Wise and Rompre 1989, Rodgers et al. 1994, Millan 2003). Great quantities of dopamine receptors are found in cerebral regions including putamen and caudate nucleus (striatum) and substantia nigra (Hurd et al. 2001), which are primarily affected by $C$. neoformans (Lee et al. 1996b, Klock et al. 2009).

\section{BRAIN ANATOMY, PHYSIOLOGY AND CRYPTOCOCCAL PATHOGENESIS}

In this section, anatomic and morphological aspects of the brain (Fig. 3) will be discussed, highlighting the physiological roles of each brain region affected by $C$. neoformans. Fig. 3 also refers to regions of the brain colonized by $C$. neoformans, so we recommend the reader to link textual descriptions with the anatomic features illustrated in this figure. We will focus on this species because it primarily infects the central nervous system (CNS), while C. gattii is more frequently associated with lung disease (Chen et al. 2000, Galanis et al. 2010, Ngamskulrungroj et al. 2012).

Clinical studies in humans in combination with animal models of neurological cryptococcosis (Lee et al. 1996b, Klock et al. 2009, Riet-Correa et al. 2011, Mandrioli et al. 2002, Sharma 2010, Robertson et al. 2014) enabled the classification of the disease into different syndromes, including meningitis, encephalitis, meningoencephalitis, ventriculitis, increased intracranial pressure (ICP), 

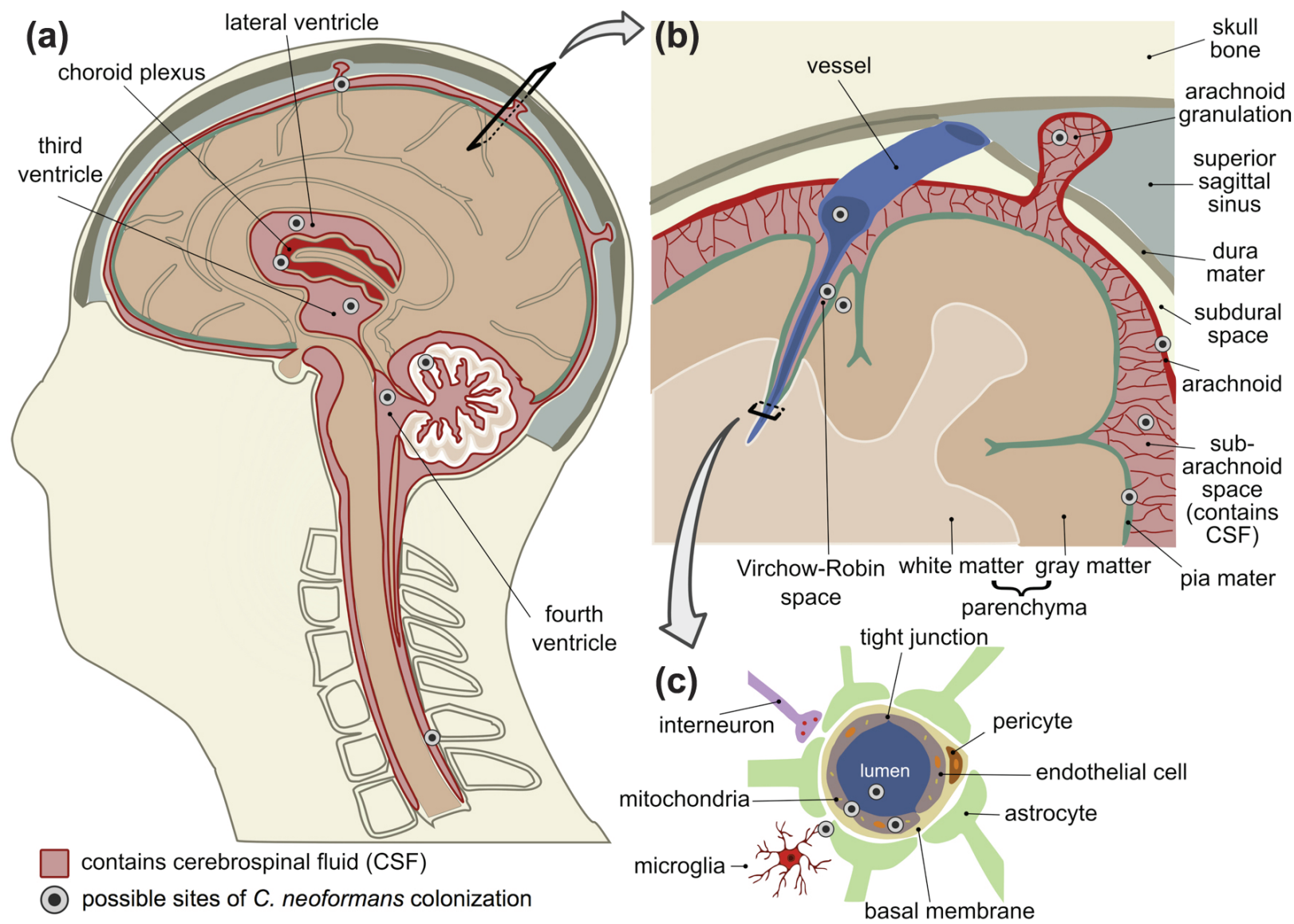

Fig. 3 - General view of the brain anatomy and areas affected by C. neoformans. a. Brain sagittal section and structures associated with the CSF. b. Coronal section of skull, meninges and parenchyma. c. Transversal section of the brain capillary and structural organization of the blood-brain barrier.

and space occupying lesion (i.e., cerebral abscesses, cysts and granulomas) (Lee et al. 1996b, Klock et al. 2009, Sharma 2010, Robertson et al. 2014). According to the National Institute for Neurological Disorders and Stroke (NINDS, <http://www. ninds.nih.gov/>), meningitis is an infection of the meninges accompanied by inflammation, while encephalitis corresponds to infection of the brain parenchyma also resulting in inflammation. Since inflammatory mechanisms usually compromise both the meninges and the parenchyma during cryptococcosis, meningoencephalitis is a common condition in patients affected by $C$. neoformans (Lee et al. 1996b, Klock et al. 2009). Infection of the ventricles has also been reported, justifying the inclusion of ventriculitis as a clinical condition related to cryptococcosis (Lee et al. 1996b). Space occupying lesions can be observed in infected individuals with the formation of cysts, abscesses or granulomas during neurological cryptococcosis (Watabe et al. 1984, Lee et al. 1996b, Kamezawa et al. 2000). Granulomas originated from $C$. neoformans infections are commonly called cryptococcomas (Chen et al. 2000, Islam et al. 2013).

\section{MENINGES}

Meninges are membranes that surround the brain and the spinal cord. Three meninges exist in mammals: dura mater, arachnoid, and pia mater (Clarke 1944, 
Decimo et al. 2012). The thicker outer layer is the dura mater, which surrounds the arachnoid. The innermost, thinner layer covering the glia is the pia mater. The nomenclature of leptomeninges for arachnoid and pia mater is often used (Tien et al. 1991, Chrétien et al. 2002, Decimo et al. 2012). The areas comprised between the meninges are the epidural or extradural (between the spinal cord or skull and the dura mater), subdural (between dura mater and arachnoid), subpial (limited by the pia mater and the glia limitants) and subarachnoid (between arachnoid and pia mater) spaces. $C$. neoformans most commonly affects arachnoid and pia mater, as well as the subarachnoid space (Watabe et al. 1984, Lee et al. 1996b, Chrétien et al. 2002, Hoang et al. 2004, Charlier et al. 2005, Pai et al. 2009). Similar profiles are observed in bacterial meningoencephalitis (Flexner 1907, Hoffman and Weber 2009). A common symptom in neurological cryptoccocosis is headache, which can be accompanied by meningismus. The latter is often associated with meningeal irritation or subarachnoid hemorrhage and is characterized by a group of clinical manifestations that include neck stiffness and photophobia (Makadzange and McHugh 2014, Graybill et al. 2000). Fever as a result of the host's inflammatory response is observed in about half of the cases (Makadzange and McHugh 2014, Satishchandra et al. 2007, Graybill et al. 2000).

\section{CEREBrospinal FLUID AND INTRACRANIAL PRESSURE}

The cerebrospinal fluid (CSF) consists of an ionic solution containing several substances to be distributed into the intracerebral environment. The CSF is responsible for providing mechanical support to the brain, controlling the chemical microenvironment, and protecting against acute blood pressure changes, sudden changes in velocity during head impacts and alterations in gravity force (Laterra et al. 1999, Strittmatter 2013).

CSF analysis after lumbar puncture (or spinal tap) is a classic tool for diagnosing infectious diseases of the CNS, including acute and chronic meningitis and acute meningoencephalitis (Machado et al. 2013). Cultures of CSF and analysis of soluble cryptococcal polysaccharides consist of the standard method for the laboratory diagnosis of neurological cryptococcosis (Mitchell and Perfect 1995, Machado et al. 2013). As reviewed by Seehusen et al. (2003), typical CSF findings in fungal meningitis are characterized by variable opening pressure, predominance of lymphocytes, elevated quantity of protein, and low CSF-to-serum glucose ratios. These features are distinct from those found in bacterial and viral meningitis (Seehusen et al. 2003). HIV-positive patients with neurological cryptococcosis tend to have high concentrations of serum and CSF polysaccharides (Diamond and Bennett 1974). However, cryptococcal polysaccharides frequently persist in CSF despite clinical improvement and negative $C$. neoformans cultures (Powderly et al. 1994). Importantly, it has been recently proposed (Sabiiti et al. 2014) that fungal proliferation occurs in the brain parenchyma rather than in the CSF, which is in agreement with the usually high CNS fungal burden (Sabiiti et al. 2014). Therefore, CSF detection of the fungus could result from spillover from both the brain and the meninges (Sabiiti et al. 2014). This supposition is in agreement with data demonstrating the existence of CSF flow in the brain parenchyma, which allows clearance of the interstitial fluid (Iliff et al. 2012). CSF flow is characterized by entrance of the fluid into the brain parenchyma via para-arterial channels of the Virchow-Robin space (VRS), and escape along the external surface of large veins (Iliff et al. 2013, Strittmatter 2013). Reentrance in the subarachnoid space or drainage into the cervical lymphatic system through the cribriform plate and the sheaths of cranial and spinal nerves are also functional in mammals (Boulton et al. 1996, Sakka et al. 2011, Strittmatter 2013).

It has been proposed in different studies that impairment of CSF resorption in the arachnoid granulations due to the accumulation of 
cryptococcal polysaccharide and/or encapsulated fungal cells, resulted in increased ICP (Denning et al. 1991, Fries et al. 2005). In fact, accumulation of cryptococcal polysaccharides can increase osmolarity of both the CSF and the interstitial fluids, promoting brain edema and increased ICP (Goldman et al. 1995). ICP has also been linked to mannitol production by the fungus (Megson et al. 1996, Hoang et al. 2004). Papilloedema (visual impairment), oculomotor palsies, and vision loss are common complications of neurologic cryptococcosis deriving from ICP in HIV patients. ICP is also linked to loss of hearing, headaches, seizures, vomiting and altered mental status, with consequent changes of behavior, decreased consciousness and lethargy (Makadzange and McHugh 2014, Perfect and Bicanic 2014, Graybill et al. 2000, Gambarin and Hamill 2002). It is clear, therefore, that ICP is related with poor prognosis.

VASCULATURE, VIRCHOW-ROBIN SPACE (VRS)

AND BLOOD-BRAIN BARRIER (BBB)

The cerebral vasculature is peculiar because vessel penetration occurs in different surface regions while in others organs there is a hilum for vessel penetration (Machado 2000). The distribution of vessels also varies depending on the brain region (Nonaka et al. 1998, 2003). Many blood vessels (arteries and veins) run within the subarachnoid space and are associated with the leptomeninges. The pial arteries at the brain surface are large cerebral vessels that branch into smaller arteries, arterioles, and capillaries. The outer layer of these arteries is separated from the brain by the VRS (Nonaka et al. 2003, Iadecola 2004, Cipolla 2009). VRS, a perivascular space, interacts with small arteries and arterioles while they penetrate the surface of the brain and extend to the parenchyma. The functional roles of the VRS include regulation of the bulk flow and drainage of interstitial fluid. The cerebral regions with detectable VRS are the thalamus, midbrain, cerebellum, extreme capsule, optical tract, hippocampus, the basal ganglia and the cortex (Pollock et al. 1997, MacLullich et al. 2004, Groeschel et al. 2006).

Imaging analysis of the brain in cryptococcosis patients suggested that the VRS was dilated in some of these individuals (Tien et al. 1991, Mathews et al. 1992, Kwee and Kwee 2007). VRS dilatation in cryptococcosis patients has been associated with the production of fungal mucoid antigens, which supposedly correspond to capsular components (Tien et al. 1991). This mucoid material is referred to as gelatinous pseudocyst (Tien et al. 1991, Mathews et al. 1992). HIV-positive patients present multiple gelatinous pseudocysts with abundant $C$. neoformans cells colonizing the VRS and adjacent areas, which is supposedly caused by the dissemination of the meningeal infection to perivascular spaces (Jain et al. 2007, Corti et al. 2008, Klock et al. 2009, Vieira et al. 2013).

The VRS disappears along with increased branching and deepness of arterioles and capillaries. Then, these deeper arterioles (intracerebral arterioles) and the capillaries (microvessels) become intimately associated with the brain tissue (Jones 1970, Iadecola 2004, Cipolla 2009). These capillaries have a specialized endothelial composition that forms the blood-brain barrier (BBB). The BBB is a selective barrier that differs from the endothelial layer of others vessels outside the nervous system because of the absence of fenestrations and presence of tight junctions between the endothelial cells. Moreover, the endothelial cells of the BBB are distinguished from those in the periphery by increased mitochondrial content and minimal pinocytotic activity (Ballabh et al. 2004, Hawkins and Davis 2005, Verkhratsky and Butt 2007, Cipolla 2009, Stanimirovic and Friedman 2012). A complex communication between cells that compose the BBB and others in the central nervous system, including the microglia and oligodendrocytes, is well known (Zlokovic 2008, Watzlawik et al. 2010, Stanimirovic and Friedman 2012). This integrated system, which has been recently classified as the neurovascular unit, operates to sustain brain homeostasis and functions 
(Ballabh et al. 2004, Hawkins and Davis 2005, Abbott et al. 2006, Verkhratsky and Butt 2007, Zlokovic 2008).

During the past decade, many studies have demonstrated that $C$. neoformans can cross the $\mathrm{BBB}$ by both direct and indirect mechanisms. Direct mechanisms include BBB passage through transcytosis of endothelial cells (Chang et al. 2004, Casadevall 2010a). Indirect mechanisms include those by which the fungus infects the brain through transit across the BBB inside phagocytes (Chrétien et al. 2002, Chang et al. 2004, Charlier et al. 2009, Shi et al. 2010, Casadevall 2010a). Mechanisms of fungal escape from infected host cells include lytic and nonlytic exocytosis (Alvarez and Casadevall 2006, Ma et al. 2006). Passage of the fungus between endothelial cells through paracellular transmigration has also been suggested to occur in cryptococcosis (Chen et al. 2003, Liu et al. 2012). Extracellular proteases might be required for degradation of the basal membrane and, consequently, crossing of the BBB during the neurological cryptococcosis (Vu et al. 2014, Rodrigues et al. 2003). It is also clear that fungal viability, urease production and morphological transition are essential for $C$. neoformans to cross the BBB (Casadevall 2010b, Shi et al. 2010). Variability in morphology, in fact, has been suggested to be fundamental for the pathogenesis of $C$. neoformans. Independent studies by the Nielsen and Zaragoza laboratories have demonstrated that both giant ( $15 \mu \mathrm{m}$ or higher) and micro-cells (lower than $1 \mu \mathrm{m}$ ) were found in infected tissues (Zaragoza et al. 2010, Zaragoza and Nielsen 2013, Zaragoza 2011, Crabtree et al. 2012, Okagaki and Nielsen 2012, Okagaki et al. 2010). These studies demonstrated that the majority of giant cells were detected in the extracellular space, while micro-cells have been frequently associated with the intracellular parasitism of macrophages. Engulfment by macrophages may facilitate dissemination and brain colonization (Casadevall 2010b).

Noteworthy, the BBB is not similarly distributed into all regions of the brain. For instance, the circumventricular organs, which contain neurons specialized in neurosecretion and/ or chemosensitivity, are not associated with the BBB (Abbott et al. 2006). Two additional layers regulate chemical and physical interactions between blood and brain tissues and / or fluids. These layers consist of the arachnoid epithelium, which forms the middle layer of the meninges, and the choroid plexus epithelium, which is located to the ventricles. The later are the major producers of CSF (Lee et al. 2001, Abbott et al. 2006, Verkhratsky and Butt 2007). C. neoformans is able to infect the choroid plexus and the ventricles, resulting in ventriculitis and/or hydrocephalus. This condition is associated to increased ICP (Lee et al. 1996b, Jain et al. 2007).

\section{BRAIN PARENCHYMA}

The brain parenchyma is a highly functional tissue composed by neurons and glial cells. An important distinction between these two cell classes is the fact that neurons manifest high electrical excitability, while glial cells do not. The glia can be sub-classified into macroglia, of ectodermal origin, and microglia, which derives from the mesoderma. Macroglial cells include astrocytes, oligodendrocytes and ependymal cells (Verkhratsky and Butt 2007). Microglial cells represent the immunoactive components of the CNS (Verkhratsky and Butt 2007, Loane and Byrnes 2010, Prinz and Priller 2014). Neurons and glial cells are not equally distributed throughout the nervous tissue, which impacts anatomical organization and important physiological functions (Lee et al. 2001, Herculano-Houzel and Lent 2005, Verkhratsky and Butt 2007).

Patients with cryptococcal encephalitis are more frequently affected in specific brain regions, including corpus striatum (globus pallidus, putamen, and caudate nucleus), midbrain (in the regions of substantia nigra), thalamus, cerebellum and superficial cerebral cortex (Lee et al. 1996b, Hoang et al. 2004, Kwee and Kwee 2007, Klock et al. 2009). The fungus also often affects the 
white matter (Lee et al. 1996b, Hoang et al. 2004). Both corpus striatum and the midbrain have been seen to respond positively to $C$. neoformans polysaccharides in HIV-positive patients (Lee et al. 1996a, Lee and Casadevall 1996). Importantly, these regions have large, penetrating vessels, dopaminergic fibers (striatonigral pathway), and manifest frequent positivity for HIV antigens (Lee et al. 1996a, b, Lee and Casadevall 1996).

The basal ganglia, one of the major structures affected by $C$. neoformans, is composed of corpus striatum (globus pallidus, putamen and caudate nucleus), substantia nigra and the subthalamic nucleus of Luys (Leisman and Melillo 2013). The roles of the basal ganglia are related to motor and cognitive functions (Leisman and Melillo 2013). The previously suggested association between neurological cryptococcosis and Parkinson's disease (Wszolek et al. 1988) might be related to the fact that the basal ganglia is affected in both diseases (Obeso et al. 2000, Sharma 2010). In fact, clinical improvement after simultaneous treatment with antifungal and anti-Parkinson agents has been reported (Wszolek et al. 1988).

It is believed that $C$. neoformans generally achieves the meninges after infection of both perivascular and subaracnoid spaces, for further colonization of the brain parenchyma (Lee et al. 1996b, Klock et al. 2009). In fact, the commonly observed accumulation of the fungus in the perivascular space supports this hypothesis (Jain et al. 2007, Corti et al. 2008, Vieira et al. 2013). Another potential route for infection of the brain parenchyma includes transit through microvessels. This haematogenous spread could be related to colonization of the subependymal zone (Lee et al. 1996b, Klock et al. 2009).

\section{BRAIN CELLS AND CRYPTOCOCCAL DISEASE}

During brain infection, C. neoformans can stimulate different host cells. Although the CNS is an immune privileged anatomic site, physiopathological mechanisms can trigger an intense brain immune response, enabling traversal of white blood cells towards the BBB (Hickey et al. 1991). Local immune responses, however, vary according to protocols of animal infection with C. neoformans (Blasi et al. 1992, Huffnagle and McNeil 1999). Intracerebral infections with $C$. neoformans usually stimulate primary CNS immune responses, while protocols resulting in subsequent brain infections (e.g. intravenous, intranasal and intratracheal) usually induce secondary CNS responses (Blasi et al. 1992, Huffnagle and McNeil 1999). The immune response activated in the CNS can include infiltration of $\mathrm{CD}^{+}$and $\mathrm{CD} 8^{+} \mathrm{T}$ cells, $\mathrm{B}$ cells, macrophages and neutrophils, as well as activation of resident cells, including the microglia, astrocytes, and endothelial cells (Blasi et al. 1995a, Lee et al. 1995a, Buchanan and Doyle 2000, Maffei et al. 2004). CNS cells, which express major histocompatibility complex classes I and II (MHC I and II) molecules and complement receptors, are able to phagocytize fungal cells and produce cytokines, chemokines and nitric oxide (NO) in response to C. neoformans antigens (Aguirre et al. 1995, Blasi et al. 1995a, Lee et al. 1995a, Huffnagle and McNeil 1999, Buchanan and Doyle 2000, Aguirre and Miller 2002, Maffei et al. 2004).

The inflammatory response in the CNS establishes later, in comparison to other anatomic sites, indicating a possible activation of $\mathrm{T}$ cells peripherally for further entrance in the CNS (Goldman et al. 1996). In fact, cryptococcomas or multinuclear giant cells containing $C$. neofomans are observed in the brain of human patients (Lee et al. 1996b, Kamezawa et al. 2000, Klock et al. 2009, Li et al. 2010, Edelman et al. 1996). Additionally, intracisternal inoculation of rats with the fungus, resulted in granuloma formation in association with the meninges, including the presence of $\mathrm{CD}^{+}$and $\mathrm{CD} 8^{+} \mathrm{T}$ cells and CD11b/c+ (Goldman et al. 1996).

Sequential steps in the immunopathogenesis of neurological cryptococcosis have been suggested in an animal model of $C$. neoformans fungemia (Chrétien et al. 2002). This model revealed moderate colonization of perivascular spaces 
3 days after infection, without inflammatory infiltrates (Chrétien et al. 2002). This initial pathogenic profile was followed, on day 8 postinfection, by formation of microcysts and induction of leptomeningitis, with discrete inflammatory infiltrates mainly composed of $\mathrm{CD}^{+}$and $\mathrm{CD} 8^{+} \mathrm{T}$ cells and minor populations of $\mathrm{B}$ cells, astrocytes and activated microglial cells (Chrétien et al. 2002). On day 15 post-infection, severe inflammation with numerous $\mathrm{CD}^{+}$and $\mathrm{CD} 8^{+} \mathrm{T}$ cells, macrophages and rare $\mathrm{B}$ cells was observed in association with the leptomeninges and inner sites of the brain. Gliosis and activation of microglial cells were also observed (Chrétien et al. 2002). In mice that recovered from the disease, sterile granulomatous lesions were observed on day 40-post infection, with positive reactions for capsular polysaccharides. These fungal antigens were also found around granulomas and inside astrocytes, microglia and leptomeningeal macrophages (Chrétien et al. 2002). These results were correlated with those found in infected human brains, except for the detection of $\mathrm{CD}^{+} \mathrm{T}$ cells (Chrétien et al. 2002). This observation is in agreement with the general immunosuppression observed in HIV patients (Mody et al. 1990, Chrétien et al. 2002). Similar models have been established for the determination of the temporal variation in cytokine responses. In these models, brain cytokines, induced in response to $C$. neoformans infection, included: IL- $1 \alpha, \mathrm{IL}^{-1}{ }^{\beta}$, IL-4, IL-6, IL-10, IFN- $\gamma$, and TNF- $\alpha$, as well as inducible nitric oxide synthase (iNOS) (Maffei et al. 2004). On day 1 after infection, IL-1 $\alpha$, TNF$\alpha$, and iNOS were elevated, while IL-4, IL-6, and IFN- $\gamma$ were induced after day 5 post-infection (Maffei et al. 2004). IL-1 ${ }^{\beta}$ and IL-10 predominated after 7 days of infection (Maffei et al. 2004).

Microglial Cells

Most of the studies about $C$. neoformans interactions with the CNS have focused on microglial cells, the most prevalent immune effectors in the brain. Microglial cells are different from other phagocytes in a number of aspects (Prinz and Priller 2014), including cellular origin and longevity, among others. These cells are primary mediators of the CNS innate immune response (Loane and Byrnes 2010, Prinz and Priller 2014), with a consequent key role in maintaining homeostasis of the brain. However, the CNS contains other phagocytes, including perivascular cells, meningeal macrophages, choroid plexus macrophages and dendritic cells (Prinz and Priller 2014). Blood-derived dendritic cells and bone marrow-derived macrophages (myeloid cells) also co-exist in the brain (Loane and Byrnes 2010, Prinz and Priller 2014).

Although microglial cells are found in all parts of the brain, their distribution is not uniform (Verkhratsky and Butt 2007). They are more abundant in the hippocampus, olfactory telencephalon, corpus striatum and the substantia nigra (Verkhratsky and Butt 2007). C. neoformans cells are usually distributed into corpus striatum and basal ganglia, where dopaminergic neurons are abundant (Lee et al. 1996b, Lee and Casadevall 1996, Klock et al. 2009). Similarly to other macrophages, microglial cells express pattern recognition receptors (PRRs). These receptors are able to detect exogenous pathogen-associated molecular patterns (PAMPs) and endogenous danger-associated molecular patterns (Figdor and van Spriel 2010). The C. neoformans major PAMPs characterized so far, are capsular polysaccharides and mannoproteins (Figdor and van Spriel 2010), which are recognized by toll-like receptors (TLRs) and mannose receptors (MRs), respectively (Figdor and van Spriel 2010). Microglial cells also express receptors for complement components, cytokines, chemokines, immunoglobulins Fc, thrombin and scavengers, as well as receptors for glutamate, GABA, and ATP (Kopp and Medzhitov 2003, Takeda and Akira 2004, Verkhratsky and Butt 2007, Loane and Byrnes 2010).

Microglial cells are promptly activated in response to brain injuries (Verkhratsky and Butt 2007, Loane and Byrnes 2010, Prinz and Priller 2014). As observed for other phagocytes, microglial 
cells can become polarized into M1- (classically activated microglia) and M2- (alternatively activated microglia) like phenotypes. These patterns are associated with the type of response triggered by the microglia (Verkhratsky and Butt 2007, Loane and Byrnes 2010, Prinz and Priller 2014). Activated microglial cells are efficient in the production of pro-inflammatory cytokines (M1-like phenotype), including IL-1 ${ }^{\beta}$, TNF- $\alpha$, IL-6 and IL-8 (Verkhratsky and Butt 2007, Prinz and Priller 2014) and chemokines (Verkhratsky and Butt 2007), enabling the recruitment of other brain macrophages and leukocytes from the bloodstream following activation of the M1-like phenotype (Prinz and Priller 2014). Depending on the microbial stimulus, microglial and other brain phagocytes can produce an anti-inflammatory response (M2-like phenotype) with production of IL-10, IL-4 and IL-13 (Verkhratsky and Butt 2007, Prinz and Priller 2014). This profile is usually required for removal of debris and stimulation of tissue regeneration, including recruitment of progenitor cells for remyelination (Prinz and Priller 2014).

Fc receptors (FcRs) of microglial cells have also been implicated in the pathogenic steps required for interaction with $C$. neoformans. The microglial receptors $\mathrm{Fc} \gamma \mathrm{RI}$ and $\mathrm{Fc} \gamma \mathrm{RIII}$ are required for production of the monocyte chemoattractant protein 1 (MIP-1a) in response to C. neoformans components in processes that require activation of extracellular signal-regulated kinase (ERK) and nuclear factor $\kappa \mathrm{B}(\mathrm{NF}-\kappa \mathrm{B})$ signaling components (Song et al. 2002). In fact, both human and murine microglial cells are able to phagocytize acapsular or opsonized C. neoformans (Blasi et al. 1992, Lee et al. 1995b, Barluzzi et al. 1998). Opsonized C. neoformans cells proliferate and produce polysaccharides within the phagolysosome of human microglial cells (Lee et al. 1995b), which has been further confirmed in models testing other phagocytes (Feldmesser et al. 2000, Tucker and Casadevall 2002, Alvarez and Casadevall 2006, Ma et al. 2006). Acapsular yeast cells are more susceptible than the encapsulated forms of C. neoformans to the antifungal activity of murine microglial cells (Barluzzi et al. 1998). Considering that $C$. neoformans cells are hypocapsular in the brain (Rivera et al. 1998), this observation might reflect an important mechanism to control fungal proliferation during neurological cryptococcosis. In fact, a number of studies suggest that capsular components are not efficient stimulators of microglial cytokine responses, such as TNF- $\alpha$ and IL-8 (Barluzzi et al. 1998, Lipovsky et al. 1998). Pigmentation, on the other hand, is apparently required for resistance against the antimicrobial activity of microglial cells (Blasi et al. 1995b). The GPR34 receptor is also highly expressed in microglial cells, as well as in granulocytic and monocytic cells (Bedard et al. 2007, Liebscher et al. 2011). This receptor, which is primarily involved with cellular chemotaxis (Bedard et al. 2007, Liebscher et al. 2011) cell motility and phagocytosis (Preissler et al. 2014) was demonstrated to be required for the control of animal cryptococcosis (Liebscher et al. 2011).

\section{MaCroglial CELls: Astrocytes}

AND OLIGODENDROCYTES

Astrocytes have multiple functions. They are important for brain physiology and development, as well as for control or progress of pathologic events (Verkhratsky and Butt 2007, Abbott et al. 2006). Astrocyte functions include regulation of synaptogenesis, maintenance of the functional architecture of the brain, BBB genesis, regulation of $\mathrm{pH}$ and osmolarity and participation in neuronal-glial signaling (Verkhratsky and Butt 2007). Astrocytes also express pattern recognition receptors, including TLR and MR (Burudi et al. 1999, Gurley et al. 2008). Other astrocyte receptors include neurotransmitter- and cytokine-binding proteins (Verkhratsky and Butt 2007, Verkhratsky 2009). The role of astrocytes in neurological cryptococcosis is poorly understood. In vitro experiments with human astrocytes have shown that stimulation of these cells with IL- ${ }^{\beta}$ and IFN- $\gamma$ 
followed by challenge with $C$. neoformans resulted in inhibition of fungal growth by nitric oxidedependent mechanisms (Brosnan et al. 1994, Lee et al. 1994). Moreover, in vivo animal experiments have shown brain astrocytes surrounding $C$. neoformans (Lee et al. 1996b, Liu et al. 2014).

Oligodendrocytes are responsible for producing the myelin sheaths that cover the axons in the CNS (Verkhratsky and Butt 2007). This process of myelination is important for electrical conductivity of the neurons (Verkhratsky and Butt 2007). Olygodendrocytes are found primarily in the white matter of the brain, since they are associated with axons (Velumian and Samoilova 2013). Except for the early suggestion that oligondendrocytes can accumulate cryptococcal polysaccharides during brain infection (Hirano et al. 1965), the role of these cells in neurological cryptococcosis is unknown.

\section{NEURONS}

Neurons are the excitatory cells of the CNS. They are generally able to respond to external stimulation by generating action potential, which is propagated through the neuronal network (Verkhratsky and Butt 2007). The communication between neurons and other cells can be of either electric or chemical natures (Verkhratsky and Butt 2007).

Fungal encephalitis is characterized by strong microglial activation and astrocytes proliferation in association with neuronal damage and reduced ability to repair affected cells (Tauber et al. 2014). Brain inflammation can be severe, depending on the regulation of apoptotic inflammatory cells and neurons (Neal and Gasque 2013). Glial cells activate death-signaling pathways to stimulate apoptosis of neutrophils, lymphocytes and damaged neurons (Neal and Gasque 2013). Live neurons can also be phagocytized by microglial cells (phagoptosis) under conditions of inflammation (Brown and Neher 2014). It has been demonstrated that NO production by astrocytes results in inhibition of C. neoformans growth (Brosnan et al. 1994). However, neurons are also susceptible to NO activity (Stewart et al. 2000). Although this observation might suggest mechanisms of neuronal damage during neurological cryptococcosis, it still requires experimental confirmation.

BRAIN MiCROVASCULAR ENDOTHELIAL CELLS (BMEC)

Neurological cryptococcosis requires crossing of the BBB by $C$. neoformans. The mechanisms by which $C$. neoformans interacts with brain microvascular endothelial cells (BMEC) are multiple and directly influenced by the fungal molecular arsenal, including hydrolytic enzymes, inositol and extracellular vesicles (Huang et al. 2012, Liu et al. 2013, Vu et al. 2014, Xu et al. 2014).

Sabiiti and May (2012) suggested that the association between fungal cells BMEC is not a frequent event. In their model, binding levels of $C$. neoformans to BMEC were low, but the percentage of internalization fungal cells was relatively high (Sabiiti and May 2012). This observation led to the hypothesis that, in neurological cryptococcosis, a low quantity of cryptococcal cells can cross the $\mathrm{BBB}$, which would be compensated by high fungal proliferation in the brain parenchyma (Sabiiti and May 2012). The capsule is apparently not directly involved in the binding and uptake of $C$. neoformans by BMEC (Sabiiti and May 2012). In fact, crossing of the BBB by the acapsular and encapsulated yeasts are apparently equivalent (Shi et al. 2010).

\section{CONCLUSIONS}

Studies on C. neoformans pathogenesis have classically focused on how capsular structures, melanin and extracellular proteins modulate the biology of immune effector cells. The role of these molecules and other potential virulence factors on brain physiology and, most importantly, neurological behavior, is unknown. The difficulties in treating human cryptococcosis and the limited knowledge on how the fungus causes damage to the brain suggest that collective efforts are required to identify new mechanisms by which $C$. neoformans 
interacts with CNS cells and how the host responds to individual fungal antigens. In this context, our literature review and recent analysis of the most evident scientific interests of the Cryptococcus community suggest the need of more intense research activity focused on the neurological response to C. neoformans infections.

\section{ACKNOWLEDGMENTS}

We are grateful to Fernanda De Felice for sharing knowledge on essential neurobiology concepts. We also appreciate the help of Leonardo Uieda for preparation of Fig. 3. ACC is a PhD student at the Program of Biological Chemistry of the Institute of Medical Biochemistry Leopoldo de Meis at the Federal University of Rio de Janeiro. MLR was supported by grants from the Brazilian agencies Fundação Carlos Chagas Filho de Amparo à Pesquisa do Estado do Rio de Janeiro (FAPERJ), Conselho Nacional de Desenvolvimento Científico e Tecnológico (CNPq) and Coordenação de Aperfeiçoamento de Pessoal de Nível Superior (CAPES), as well as by the Instituto Nacional de Ciência e Tecnologia de Inovação em Doenças Negligenciadas (INCT-IDN). MLR is the recipient of a Pathfinder Award from the Wellcome Trust (UK).

\section{RESUMO}

Infecção do cérebro pelo fungo Cryptococcus neoformans resulta em um estimado de 500.000 mortes de pessoas por ano. A colonização do sistema nervoso central (SNC) pelo C. neoformans causa diversas síndromes clínicas que envolvem a interação de um número de componentes de fungo com distintas células do cérebro. Nesse artigo, nossa revisão da literatura confirmou a ideia de que a área de Cryptococcus está em rápida expansão, mas também sugeriu que os estudos sobre neuropatogênese ainda representam uma fração pequena da atividade de pesquisas básicas no campo. Nós, portanto, discutimos aspectos anatômicos e fisiológicos do cérebro durante a infecção pelo C. neoformans, além dos mecanismos pelos quais as células residentes do cérebro interagem com o fungo. Essa revisão sugere que esforços múltiplos são necessários para aprofundar o conhecimento sobre como o C. neoformans afeta as células do cérebro, para permitir a geração de novas ferramentas terapêuticas em futuro próximo.

Palavras-chave: Infecções Fúngicas, Cryptococcus, meningite, meningoencefalite.

\section{REFERENCES}

ABBotT NJ, RonNBACK L AND HANSSON E. 2006. Astrocyteendothelial interactions at the blood-brain barrier. Nat Rev Neurosci 7: 41-53.

Aguirre K, HaVell EA, Gibson GW and Johnson LL. 1995. Role of tumor necrosis factor and gamma interferon in acquired resistance to Cryptococcus neoformans in the central nervous system of mice. Infect Immun 63: 17251731.

Aguirre K And Miller S. 2002. MHC class II-positive perivascular microglial cells mediate resistance to Cryptococcus neoformans brain infection. Glia 39: 184188.

AlbuQuerque PC AND RodRIGUes ML. 2012. Research trends on pathogenic Cryptococcus species in the last 20 years: a global analysis with focus on Brazil. Future Microbiol 7: 319-329.

Alvarez M and Casadevall A. 2006. Phagosome extrusion and host-cell survival after Cryptococcus neoformans phagocytosis by macrophages. Curr Biol 16: 2161-2165.

Armstrong-James D, MEINTJEs G AND BROWN GD. 2014. A neglected epidemic: fungal infections in HIV/AIDS. Trends Microbiol 22: 120-127.

Ballabh P, Braun A And NedergaArd M. 2004. The blood-brain barrier: an overview: structure, regulation, and clinical implications. Neurobiol Dis 16: 1-13.

BARluzzi R, BRozzetti A, DElFino D, Bistoni F AND BLASI E. 1998. Role of the capsule in microglial cellCryptococcus neoformans interaction: impairment of antifungal activity but not of secretory functions. Med Mycol 36: 189-197.

Bedard A, TREMBlay P, CHERNOMORETZ A AND VALLIERES L. 2007. Identification of genes preferentially expressed by microglia and upregulated during cuprizone-induced inflammation. Glia 55: 777-789.

Blasi E, BARluzzi R, MAzZOLla R, Mosci P AND Bistoni F. 1992. Experimental model of intracerebral infection with Cryptococcus neoformans: roles of phagocytes and opsonization. Infect Immun 60: 3682-3688.

Blasi E, Barluzzi R, Mazzolla R, Pitzurra L, Puliti M, SALEPPICO S AND BISTONI F. 1995a. Biomolecular events involved in anticryptococcal resistance in the brain. Infect Immun 63: 1218-1222. 
Blasi E, Barluzzi R, Mazzolla R, TANCini B, SAleppico S, Puliti M, Pitzurra L And Bistoni F. 1995b. Role of nitric oxide and melanogenesis in the accomplishment of anticryptococcal activity by the BV-2 microglial cell line. J Neuroimmunol 58: 111-116.

Boulton M, Young A, Hay J, Armstrong D, Flessner M, SCHWARTZ M AND JOHNSTON M. 1996. Drainage of CSF through lymphatic pathways and arachnoid villi in sheep: measurement of 125I-albumin clearance. Neuropathol Appl Neurobiol 22: 325-333.

Brizendine KD, Baddley JW AND Pappas PG. 2011. Pulmonary cryptococcosis. Semin Respir Crit Care Med 32: 727-734.

Brosnan CF, Battistini L, Raine CS, Dickson DW, CASAdevall A AND LeE SC. 1994. Reactive nitrogen intermediates in human neuropathology: an overview. Dev Neurosci 16: 152-161.

BROWN GC AND NeHER JJ. 2014. Microglial phagocytosis of live neurons. Nat Rev Neurosci 15: 209-216.

BUCHANAN KL AND DOYLE HA. 2000. Requirement for CD4(+) T lymphocytes in host resistance against Cryptococcus neoformans in the central nervous system of immunized mice. Infect Immun 68: 456-462.

BuRUdi EM, RiESE S, STAHL PD AND REGNIER-VIGOUROUX A. 1999. Identification and functional characterization of the mannose receptor in astrocytes. Glia 25: 44-55.

Casadevall A. 2010a. Cryptococci at the brain gate: break and enter or use a Trojan horse? J Clin Invest 120: 13891392.

Casadevall A. 2010b. Cryptococci at the brain gate: break and enter or use a Trojan horse? J Clin Invest 120: 13891392.

Chang YC, Stins MF, Mccaffery MJ, Miller GF, Pare DR, DAM T, PAUl-Satyaseela M, Kim KS AND KWONChUng KJ. 2004. Cryptococcal yeast cells invade the central nervous system via transcellular penetration of the blood-brain barrier. Infect Immun 72: 4985-4995.

Charlier C, Chretien F, Baudrimont M, Mordelet E, LORTHOLARY O AND DROMER F. 2005. Capsule structure changes associated with Cryptococcus neoformans crossing of the blood-brain barrier. Am J Pathol 166: 421432.

Charlier C, Nielsen K, Daou S, Brigitte M, Chretien F AND DROMER F. 2009. Evidence of a role for monocytes in dissemination and brain invasion by Cryptococcus neoformans. Infect Immun 77: 120-127.

Chayakulkeeree M ANd Perfect JR. 2006. Cryptococcosis. Infect Dis Clin N. Am 20: 507-544.

Chen S, Sorrell T, Nimmo G, Speed B, Currie B, Ellis D, Marriott D, Pfeiffer T, Parr D AND Byth K. 2000. Epidemiology and host- and variety-dependent characteristics of infection due to Cryptococcus neoformans in Australia and New Zealand. Australasian Cryptococcal Study Group. Clin Infect Dis 31: 499-508.

Chen SH, Stins MF, HuAng SH, Chen YH, KwON-Chung KJ, Chang Y, Kim KS, SuzuKi K And Jong AY. 2003. Cryptococcus neoformans induces alterations in the cytoskeleton of human brain microvascular endothelial cells. J Med Microbiol 52: 961-970.

Chrétien F, Lortholary O, Kansau I, Neuville S, GraY F AND DROMER F. 2002. Pathogenesis of cerebral Cryptococcus neoformans infection after fungemia. J Infect Dis 186: 522-530.

Cipolla MJ. 2009. The Cerebral Circulation, San Rafael (CA): Morgan \& Claypool Life Sciences; 2009. Available from: http:/www.ncbi.nlm.nih.gov/books/NBK53081/

Clarke AG. 1944. The Anatomy of the Meninges. Postgrad Med J 20: 74-78.

Corti M, Villafane MF, Negroni R, Arechavala A AND MAIOLO E. 2008. Magnetic resonance imaging findings in AIDS patients with central nervous system cryptococcosis. Rev Iberoam Micol 25: 211-214.

Crabtree JN, Okagaki LH, Wiesner DL, Strain AK, NiELSEN JN AND NIELSEN K. 2012. Titan cell production enhances the virulence of Cryptococcus neoformans. Infect Immun 80: 3776-3785.

Decimo I, Fumagalli G, Berton V, Krampera M And BIFARI F. 2012. Meninges: from protective membrane to stem cell niche. Am J Stem Cells 1: 92-105.

DenNing DW, ARMSTRONG RW, LeWIS BH AND STEVENS DA. 1991. Elevated cerebrospinal fluid pressures in patients with cryptococcal meningitis and acquired immunodeficiency syndrome. Am J Med 91: 267-272.

DiAmOND RD AND BENNETT JE. 1974. Prognostic factors in cryptococcal meningitis. A study in 111 cases. Ann Intern Med 80: 176-181.

Edelman M, Birkenhauer MC, Steinberg JJ, Dickson DW, CASADEVAll A AND LeE SC. 1996. Microglial nodule encephalitis: limited CNS infection despite disseminated systemic cryptococcosis. Clin Neuropathol 15: 30-33.

EisenMan HC, Frases S, Nicola AM, Rodrigues ML AND CASADEVAll A. 2009. Vesicle-associated melanization in Cryptococcus neoformans. Microbiology 155: 3860-3867.

Feldmesser M, Kress Y, Novikoff P AND CASAdevall A. 2000. Cryptococcus neoformans is a facultative intracellular pathogen in murine pulmonary infection. Infect Immun 68: 4225-4237.

Figdor CG AND VAN SPRIEL AB. 2010. Fungal patternrecognition receptors and tetraspanins: partners on antigenpresenting cells. Trends Immunol 31: 91-96.

FLEXNER S. 1907. Experimental Cerebro-Spinal Meningitis In Monkeys. J Exp Med 9: 142-167.

Fries BC, LeE SC, Kennan R, Zhao W, Casadevall A AND Goldman DL. 2005. Phenotypic switching of Cryptococcus neoformans can produce variants that 
elicit increased intracranial pressure in a rat model of cryptococcal meningoencephalitis. Infect Immun 73: 1779-1787.

Galanis E, Macdougall L, Kidd S AND Morshed M. 2010. Epidemiology of Cryptococcus gattii, British Columbia, Canada, 1999-2007. Emerg Infect Dis 16: 251-257.

Gambarin KJ And Hamill RJ. 2002. Management of Increased Intracranial Pressure in Cryptococcal Meningitis. Curr Infect Dis Rep 4: 332-338.

Goldman DL, Casadevall A, Cho Y AND Lee SC. 1996. Cryptococcus neoformans meningitis in the rat. Lab Invest 75: 759-770.

Goldman DL, LeE SC AND CASAdevall A. 1995. Tissue localization of Cryptococcus neoformans glucuronoxylomannan in the presence and absence of specific antibody. Infect Immun 63: 3448-3453.

Graybill JR, Sobel J, SaAg M, VAn der Horst C, Powderly W, Cloud G, Riser L, Hamill R and Dismukes W. 2000. Diagnosis and management of increased intracranial pressure in patients with AIDS and cryptococcal meningitis. The NIAID Mycoses Study Group and AIDS Cooperative Treatment Groups. Clin Infect Dis 30: 47-54.

Groeschel S, Chong WK, Surtees R and Hanefeld F. 2006. Virchow-Robin spaces on magnetic resonance images: normative data, their dilatation, and a review of the literature. Neuroradiology 48: 745-754.

Gurley C, Nichols J, Liu S, Phulwani NK, EsEN N AND KIELIAN T. 2008. Microglia and Astrocyte Activation by Toll-Like Receptor Ligands: Modulation by PPAR-gamma Agonists. PPAR Research 2008: 453120.

HAWKINS BT AND DAVIS TP. 2005. The blood-brain barrier/ neurovascular unit in health and disease. Pharmacol Rev 57: $173-185$.

HerCulano-Houzel S AND LENT R. 2005. Isotropic fractionator: a simple, rapid method for the quantification of total cell and neuron numbers in the brain. J Neurosci 25: 2518-2521.

Hickey WF, Hsu BL AND Kimura H. 1991. T-lymphocyte entry into the central nervous system. J Neurosci Res 28 : 254-260.

Hirano A, Zimmerman HM And Levine S. 1965. Fine Structure of Cerebral Fluid Accumulation. Vi. Intracellular Accumulation of Fluid and Cryptococcal Polysaccharide in Oligodendroglia. Arch Neurol 12: 189-196.

HoAng LM, Maguire JA, Doyle P, Fyfe M And Roscoe DL. 2004. Cryptococcus neoformans infections at Vancouver Hospital and Health Sciences Centre (19972002): epidemiology, microbiology and histopathology. J Med Microbiol 53: 935-940.

HofFMAN O AND WeBer RJ. 2009. Pathophysiology and treatment of bacterial meningitis. Ther Adv Neurol Disord 2: $1-7$.
HuANG SH, Wu CH, Chang YC, KwON-Chung KJ, Brown RJ AND JONG A. 2012. Cryptococcus neoformans-derived microvesicles enhance the pathogenesis of fungal brain infection. PloS one 7: e48570.

Huffnagle GB and MCNeIL LK. 1999. Dissemination of $C$. neoformans to the central nervous system: role of chemokines, Th1 immunity and leukocyte recruitment. J Neurovirol 5: 76-81.

Hurd YL, SuZuKI M AND SEDVAll GC. 2001. D1 and D2 dopamine receptor mRNA expression in whole hemisphere sections of the human brain. J Chem Neuroanat 22: 127-137.

IADECOLA C. 2004. Neurovascular regulation in the normal brain and in Alzheimer's disease. Nat Rev Neurosci 5: 347-360.

Iliff JJ, LeE H, Yu M, Feng T, LogAn J, NedergaARd M AND BENVENISTE H. 2013. Brain-wide pathway for waste clearance captured by contrast-enhanced MRI. J Clin Invest 123: 1299-1309.

ILIFF JJ ET AL. 2012. A paravascular pathway facilitates CSF flow through the brain parenchyma and the clearance of interstitial solutes, including amyloid beta. Sci Transl Med 4: 147ra111.

ISLAM A, LI SS, OYKHMAN P, TIMM-MCCANN M, HUSTON SM, Stack D, Xiang RF, Kelly MM and Mody CH. 2013. An acidic microenvironment increases NK cell killing of Cryptococcus neoformans and Cryptococcus gattii by enhancing perforin degranulation. PLoS Pathog 9: e1003439.

JAin KK, Mittal SK, Kumar S AND GuptA RK. 2007. Imaging features of central nervous system fungal infections. Neurol India 55: 241-250.

JONES EG. 1970. On the mode of entry of blood vessels into the cerebral cortex. J Anat 106: 507-520.

Kamezawa T, Shimozuru T, Nitro M, Nagata S AND KURATSU J. 2000. MRI of a cerebral cryptococcal granuloma. Neuroradiology 42: 441-443.

KlOCK C, CERSKi M AND Goldani LZ.2009. Histopathological aspects of neurocryptococcosis in HIV-infected patients: autopsy report of 45 patients. Int J Sur Pathol 17: 444-448.

Kopp E AND MedZHitov R. 2003. Recognition of microbial infection by Toll-like receptors. Curr Opin Immunol 15: 396-401.

KWEE RM AND KWEE TC. 2007. Virchow-Robin spaces at MR imaging. Radiographics 27: 1071-1086.

LATERRA J, KeEP R, Betz LA AND GOLdSTEIn GW. 1999. Blood-Cerebrospinal Fluid Barrier. In: Siegel GJ, Agranoff BW, Alberts RW, Fisher SK and Uhler MD (Eds), Basic Neurochemistry: Molecular, Cellular and Medical Aspects, $6^{\text {th }}$ ed., Philadelphia: Lippincott-Raven. Available from: http://www.ncbi.nlm.nih.gov/books/NBK27998/

Lee G, Dallas S, Hong M and Bendayan R. 2001. Drug transporters in the central nervous system: brain barriers 
and brain parenchyma considerations. Pharmacol Rev 53: 569-596.

LeE SC AND CASAdeVAll A. 1996. Polysaccharide antigen in brain tissue of AIDS patients with cryptococcal meningitis. Clin Infect Dis 23: 194-195.

LeE SC, CASAdevall A AND Dickson DW. 1996a. Immunohistochemical localization of capsular polysaccharide antigen in the central nervous system cells in cryptococcal meningoencephalitis. Am J Pathol 148: 1267-1274.

Lee SC, Dickson DW, Brosnan CF and Casadevall A. 1994. Human astrocytes inhibit Cryptococcus neoformans growth by a nitric oxide-mediated mechanism. J Exp Med 180: 365-369.

Lee SC, Dickson DW and Casadevall A. 1996b. Pathology of cryptococcal meningoencephalitis: analysis of 27 patients with pathogenetic implications. Hum Pathol 27: 839-847.

Lee SC, Kress Y, Dickson DW and Casadevall A. 1995a. Human microglia mediate anti-Cryptococcus neoformans activity in the presence of specific antibody. $\mathrm{J}$ Neuroimmunol 62: 43-52.

LEE SC, KRESS Y, ZHAO ML, DiCKSON DW AND CASADEVALL A. 1995b. Cryptococcus neoformans survive and replicate in human microglia. Lab Investigat 73: 871-879.

LEISMAN G AND MELILLO R. 2013. The basal ganglia: motor and cognitive relationships in a clinical neurobehavioral context. Rev Neurosci 24: 9-25.

Lester SJ, MALiK R, BARTLETt KH AND DunCAN CG. 2011. Cryptococcosis: update and emergence of Cryptococcus gattii. Pathol 40: 4-17.

LI Q, You C, LIU Q AND LIU Y. 2010. Central nervous system cryptococcoma in immunocompetent patients: a short review illustrated by a new case. Acta Neurochir 152: 129-136.

LIEBSCHER I ET AL. 2011. Altered immune response in mice deficient for the $\mathrm{G}$ protein-coupled receptor GPR34. J Biol Chem 286: 2101-2110.

Lipovsky MM, GeKKer G, HU S, Ehrlich LC, Hoepelman AI ANd PeTerson PK. 1998. Cryptococcal glucuronoxylomannan induces interleukin (IL)-8 production by human microglia but inhibits neutrophil migration toward IL-8. J Infect Dis 177: 260-263.

LiU L, WaKamatsu K, Ito S AND Williamson PR. 1999. Catecholamine oxidative products, but not melanin, are produced by Cryptococcus neoformans during neuropathogenesis in mice. Infect Immun 67: 108-112.

LiU TB, Kim JC, WANG Y, Toffaletti DL, Eugenin E, PERFECT JR, KIM KJ AND XUE C. 2013. Brain inositol is a novel stimulator for promoting Cryptococcus penetration of the blood-brain barrier. PLoS Pathog 9: e1003247.

LIU TB, PERLIN DS AND XUE C. 2012. Molecular mechanisms of cryptococcal meningitis. Virulence 3: 173-181.
Liu TB, Subbian S, Pan W, Eugenin E, Xie J and Xue C. 2014. Cryptococcus inositol utilization modulates the host protective immune response during brain infection. Commun Signal 12: 51.

LOANE DJ AND BYRNES KR. 2010. Role of microglia in neurotrauma. Neurotherapeutics 7: 366-377.

MA H, Croudace JE, Lammas DA and May RC. 2006. Expulsion of live pathogenic yeast by macrophages. Curr Biol 16: 2156-2160.

Machado ABM. 2000. Neuroanatomia Funcional. $2^{\mathrm{a}}$ ed., São Paulo: Atheneu, 2000.

Machado R, LiVRamento JA And Vianna LS. 2013. Cerebrospinal fluid analysis in infectious diseases of the nervous system: when to ask, what to ask, what to expect. Arq Neuro-Psiquatr 71: 693-698.

MacLullich AM, WardlaW JM, Ferguson KJ, Starr JM, SECKL JR AND DEARY IJ. 2004. Enlarged perivascular spaces are associated with cognitive function in healthy elderly men. J Neurol Neurosurg Psychiatry 75: 15191523.

Maffei CM, Mirels LF, Sobel RA, Clemons KV AND STEVENS DA. 2004. Cytokine and inducible nitric oxide synthase mRNA expression during experimental murine cryptococcal meningoencephalitis. Infect Immun 72 : 2338-2349.

MaKadzange AT AND McHugh G. 2014. New approaches to the diagnosis and treatment of cryptococcal meningitis. Semin Neurol 34: 47-60.

Mandrioli L, Bettini G, Marcato PS, Benazzi C, Della SAlda L, Krockenberger MB AND Jensen HE. 2002. Central nervous system cryptococcoma in a cat. J Vet Med A Physiol Pathol Clin Med 49: 526-530.

MatheWs VP, Alo PL, GLASS JD, KUMAR AJ AND MCARTHUR JC. 1992. AIDS-related CNS cryptococcosis: radiologicpathologic correlation. AJNR Am J Neuroradiol 13: $1477-$ 1486.

Megson GM, Stevens DA, Hamilton JR And Denning DW. 1996. D-mannitol in cerebrospinal fluid of patients with AIDS and cryptococcal meningitis. J Clin Microbiol 34: $218-221$.

MiLLAN MJ. 2003. The neurobiology and control of anxious states. Prog Neurobiol 70: 83-244.

Mitchell TG AND PeRfect JR. 1995. Cryptococcosis in the era of AIDS - 100 years after the discovery of Cryptococcus neoformans. Clin Microbiol Rev 8: 515-548.

Mody CH, Lipscomb MF, StReet NE AND Toews GB. 1990. Depletion of CD4+ (L3T4+) lymphocytes in vivo impairs murine host defense to Cryptococcus neoformans. J Immunol (Baltimore, Md: 1950) 144: 1472-1477.

NEAL JW AND GASQUE P. 2013. How does the brain limit the severity of inflammation and tissue injury during bacterial meningitis? J Neuropathol Exp Neurol 72: 370-385. 
Ngamskulrungroj P, Chang Y, Sionov E AND KwONCHUNG KJ. 2012. The primary target organ of Cryptococcus gattii is different from that of Cryptococcus neoformans in a murine model. mBio 3: e00103-00112.

NONAKA H, AKIMA M, NAgAYAMA T, HATORI T AND ZHANG Z. 1998. The fundamental architecture of the microvasculature of the basal ganglia and changes in senility. Neuropathology 18: 47-54.

NonaKa H, AKima M, Nagayama T, Hatori T, Zhang Z AND IHARA F. 2003. Microvasculature of the human cerebral meninges. Neuropathology 23: 129-135.

Nosanchuk JD, Rosas AL, Lee SC and Casadevall A. 2000. Melanisation of Cryptococcus neoformans in human brain tissue. Lancet 355: 2049-2050.

Nosanchuk JD, Valadon P, Feldmesser M AND Casadevall A. 1999. Melanization of Cryptococcus neoformans in murine infection. Mol Cell Biol 19: 745750.

Obeso JA, Rodriguez-Oroz MC, Rodriguez M, LANCIEGO JL, Artieda J, Gonzalo N and Olanow CW. 2000. Pathophysiology of the basal ganglia in Parkinson's disease. Trends Neurosci 23: S8-19.

OKagaki LH AND Nielsen K. 2012. Titan cells confer protection from phagocytosis in Cryptococcus neoformans infections. Eukaryotic Cell 11: 820-826.

OKagaki LH, Strain AK, Nielsen JN, Charlier C, Baltes NJ, Chretien F, Heitman J, Dromer F and Nielsen K. 2010. Cryptococcal cell morphology affects host cell interactions and pathogenicity. PLoS Pathog 6: e1000953.

Pai MP, Sakoglu U, Peterson SL, Lyons CR AND Sood R. 2009. Characterization of BBB permeability in a preclinical model of cryptococcal meningoencephalitis using magnetic resonance imaging. J Cereb Blood Flow Metab 29: 545-553.

PARK BJ, WANNemuehler KA, Marston BJ, Govender N, PAPPAS PG AND CHILler TM. 2009. Estimation of the current global burden of cryptococcal meningitis among persons living with HIV/AIDS. Aids 23: 525-530.

PERFECT JR AND BICANIC T. 2014. Cryptococcosis diagnosis and treatment: What do we know now. Fungal Genet Biol 2015 78: 49-54.

Pollock H, Hutchings M, Weller RO And Zhang ET. 1997. Perivascular spaces in the basal ganglia of the human brain: their relationship to lacunes. J Anat 191( Pt 3): 337-346.

Powderly WG, Cloud GA, Dismukes We and SAAG MS. 1994. Measurement of cryptococcal antigen in serum and cerebrospinal fluid: value in the management of AIDSassociated cryptococcal meningitis. Clin infect Dis 18: 789-792.

Prado M, Silva MB, Laurenti R, TraVassos LR AND TABORDA CP. 2009. Mortality due to systemic mycoses as a primary cause of death or in association with AIDS in Brazil: a review from 1996 to 2006. Mem Inst Oswaldo Cruz 104: 513-521.

PREISSLER J ET AL. 2014. Altered microglial phagocytosis in GPR34-deficient mice. Glia 2015 63: 206-215.

PRICE MS AND PERfECT JR. 2011. Host defenses against cryptococcosis. Immunol Invest 40: 786-808.

Prinz M AND PRILler J. 2014. Microglia and brain macrophages in the molecular age: from origin to neuropsychiatric disease. Nat Rev Neurosci 15: 300-312.

Riet-Correa F, Krockenberger M, DAntas AF AND OLIVEIRA DM. 2011. Bovine cryptococcal meningoencephalitis. J Viet Diagn Invest 23: 1056-1060.

Rivera J, Feldmesser M, CAMmer M AND CASAdEVAll A. 1998. Organ-dependent variation of capsule thickness in Cryptococcus neoformans during experimental murine infection. Infect Immun 66: 5027-5030.

ROBERTSON EJ ET AL. 2014. Cryptococcus neoformans ex vivo capsule size is associated with intracranial pressure and host immune response in HIV-associated cryptococcal meningitis. J Infect Dis 209: 74-82.

Rodgers RJ, NiKulina EM AND COLE JC. 1994. Dopamine D1 and D2 receptor ligands modulate the behaviour of mice in the elevated plus-maze. Pharmacol Biochem Behav 49: 985-995.

Rodrigues ML, Dos Reis FC, Puccia R, Travassos LR AND ALVIANO CS. 2003. Cleavage of human fibronectin and other basement membrane-associated proteins by a Cryptococcus neoformans serine proteinase. Microbial Pathogenesis 34: 65-71.

Rosas AL, Nosanchuk JD, Feldmesser M, Cox GM, McDade HC AND Casadevall A. 2000. Synthesis of polymerized melanin by Cryptococcus neoformans in infected rodents. Infect Immun 68: 2845-2853.

Roy M AND ChILler T. 2011. Preventing deaths from cryptococcal meningitis: from bench to bedside. Rev Anti Infect Ther 9: 715-717.

SABIITI W AND MAY RC. 2012. Capsule independent uptake of the fungal pathogen Cryptococcus neoformans into brain microvascular endothelial cells. PloS one 7: e35455.

SABIITI W ET AL. 2014. Efficient phagocytosis and laccase activity affect the outcome of HIV-associated cryptococcosis. J Clin Invest 124: 2000-2008.

SAKKA L, Coll G And Chazal J. 2011. Anatomy and physiology of cerebrospinal fluid. Eur Ann Otorhinolaringol Head Neck Dis 128: 309-316.

SAlas SD, Bennett JE, Kwon-Chung KJ, Perfect JR AND WILLIAMSON PR. 1996. Effect of the laccase gene CNLAC1, on virulence of Cryptococcus neoformans. J Exp Med 184: 377-386.

SATISHChandRa P, MATHEW T, GADRE G, NAGARATHNA S, ChandramuKhi A, Mahadevan A AND SHanKar SK. 2007. Cryptococcal meningitis: clinical, diagnostic and therapeutic overviews. Neurol India 55: 226-232. 
Seehusen DA, ReEves MM And Fomin DA. 2003. Cerebrospinal fluid analysis. Am Fam Physician 68: 11031108.

SHARMA RR. 2010. Fungal infections of the nervous system: current perspective and controversies in management. Int J Surg (London, England) 8: 591-601.

Shi M, LI SS, Zheng C, Jones GJ, Kim KS, Zhou H, Kubes $\mathrm{P}$ AND Mody CH. 2010. Real-time imaging of trapping and urease-dependent transmigration of Cryptococcus neoformans in mouse brain. J Clin Invest 120: 1683-1693.

Song X, Shapiro S, Goldman DL, Casadevall A, SCHARFF M AND LEE SC. 2002. Fcgamma receptor I- and III-mediated macrophage inflammatory protein 1alpha induction in primary human and murine microglia. Infect Immun 70: 5177-5184.

StANIMIROVIC DB AND FrIEDMAN A. 2012. Pathophysiology of the neurovascular unit: disease cause or consequence? J Cereb Blood Flow Metab 32: 1207-1221.

Stewart VC, Sharpe MA, Clark JB AND Heales SJ. 2000. Astrocyte-derived nitric oxide causes both reversible and irreversible damage to the neuronal mitochondrial respiratory chain. J Neurochem 75: 694-700.

StRITTMATtER WJ. 2013. Bathing the brain. J Clin Invest 123: 1013-1015.

TAKEDA K AND AKIRA S. 2004. TLR signaling pathways. Semin Immunol 16: 3-9.

TAUBer SC, EIFFERT H, KELlNER S, LUGERT R, BUNKOWSKI S, Schutze S, Perske C, Bruck W and Nau R. 2014. Fungal encephalitis in human autopsy cases is associated with extensive neuronal damage but only minimal repair. Neuropathol Appl Neurobiol 40: 610-627.

TERADA T. 2010. Cryptococcosis in the central nervous system in a 36-year-old Japanese man: an autopsy study. Tohoku J Exp Med 222: 33-37.

Tien RD, Chu PK, Hesselink JR, Duberg A AND Wiley C. 1991. Intracranial cryptococcosis in immunocompromised patients: CT and MR findings in 29 cases. AJNR Am J Neuroradiol 12: 283-289.

Tucker SC And CASAdevall A. 2002. Replication of Cryptococcus neoformans in macrophages is accompanied by phagosomal permeabilization and accumulation of vesicles containing polysaccharide in the cytoplasm. Proc Nat Acad Sci USA 99: 3165-3170.

Velumian A And Samoilova M. 2013. White Matter: Basic Principles of Axonal Organization and Function. In: Baltan S, Carmichael ST, Matute C, Xi G and Zhang JH (Eds), White Matter Injury in Stroke and CNS Disease, p. 608.

VERKHRATSKY A. 2009. Neurotransmitter Receptors in Astrocytes. In: Haydon PG and Parpura V (Eds),
Astrocytes in (Patho) Physiology of the Nervous System: Springer US, p. 49-67.

VERKHRATSKY A AND BUTT AM. 2007. Glial Neurobiology: a textbook. $1^{\text {st }}$ ed., England: J Wiley \& Sons, 230 p.

Vieira MA, Costa CH, Ribeiro JC, Nunes-Filho LP, Rabelo MG AND Almeida-Neto WS. 2013. Soap bubble appearance in brain magnetic resonance imaging: cryptococcal meningoencephalitis. Rev Soc Bras Med Trop 46: 658-659.

Vu K, THAM R, UHRIG JP, THOMPSON GR 3RD, NA POMBEJRA S, JAMKLANG M, BAutos JM AND Gelli A. 2014. Invasion of the central nervous system by Cryptococcus neoformans requires a secreted fungal metalloprotease. mBio 5: e01101-01114.

WatABE T, MiyaJi M AND Nishimura K. 1984. Studies on relationship between cysts and granulomas in murine cryptococcosis. Mycopathologia 86: 113-120.

WATZLAWIK J, WARRINGTON A AND RODRIGUEZ M. 2010. Importance of oligodendrocyte protection, blood brain barrier breakdown and inflammation for remyelination. Expert Rev Neurother 10: 441-457.

WISE RA AND ROMPRE PP. 1989. Brain dopamine and reward. Annu Rev Psychol 40: 191-225.

Wszolek Z, Monsour H, SMith P ANd Pfeiffer R. 1988. Cryptococcal meningoencephalitis with parkinsonian features. Mov Disord 3: 271-273.

Xu CY, ZHu HM, Wu JH, WEN H AND LIU CJ. 2014. Increased permeability of blood-brain barrier is mediated by serine protease during Cryptococcus meningitis. J Int Med Res 42: 85-92.

Zaragoza O. 2011. Multiple Disguises for the Same Party: The Concepts of Morphogenesis and Phenotypic Variations in Cryptococcus neoformans. Front Microbiol 2: 181.

Zaragoza O, GARCIA-RODAS R, NOSANCHUK JD, CUENCAESTRElla M, RodriguEZ-TUdELA JL AND CASADEVALL A. 2010. Fungal cell gigantism during mammalian infection. PLoS Pathog 6: e1000945.

ZaragozA O AND Nielsen K. 2013. Titan cells in Cryptococcus neoformans: cells with a giant impact. Curr Opin Microbiol 16: 409-413.

Zaragoza O, Rodrigues ML, De Jesus M, Frases S, Dadachova E AND CASAdEVAll A. 2009. The capsule of the fungal pathogen Cryptococcus neoformans. Adv Appl Microbioly 68: 133-216.

ZHU X AND WILLIAMSON PR. 2004. Role of laccase in the biology and virulence of Cryptococcus neoformans. FEMS Yeast Res 5: 1-10.

ZLOKOVIC BV. 2008. The blood-brain barrier in health and chronic neurodegenerative disorders. Neuron 57: 178-201. 